\title{
PERENCANAAN DAN PENGADAAN OBAT DI PUSKESMAS “X” BERDASARKAN PERMENKES NOMOR 74 TAHUN 2016
}

Drug Planning and Procurement in Public Health Center " $X$ " Based on

Regulation of Health Minister Number 74 Year 2016

Fathiyah Rahma

Perhimpunan Sarjana dan Profesional Kesehatan Masyarakat Indonesia (Persakmi) Kota Surabaya, Indonesia E-mail: imarahma27@gmail.com

\begin{abstract}
Drugs and medical consumable planning and procurement which contained both flaw and inaccuracy are likely affecting their sustainability in Public Health Center (Puskesmas). This paper aims to study mechanism of drugs planning and procurement implemented by in Puskesmas " $X$ ". This was a descriptive research using qualitative approach emphasizing on observational method. This study found there were two sources of drug financing and medical consumable in Puskesmas " $X$ ", using the Revenue and Expense Budgeting of the local administration or else, using capitation funds from National Health Coverage program. Drugs planning that financed using the local government revenues and expenses budgeting scheme. Performed under the basis of drug usage that annually reported. Such planning were conducted in the end of the year to project next year drugs' consumption. Drugs procurement process were performed by preparing drugs consumption report and ordering sheet paper which then submitted to drug logistics unit at Puskesmas " $X$ ". Afterwards, procurement processes were performed by accessing e-catalogue as the legal online system provided by the national government. This research concluded that the implementation of the planning and procurement of drugs in Puskesmas has fulfilled and followed in accordance with Health Ministry Regulation Number 74 Year 2016.
\end{abstract}

Keywords: drugs planning, drugs procurement, regulation public health center

\section{ABSTRAK}

Kualitas perencanaan obat dan bahan medis habis pakai dalam kegiatan pengadaan obat yang lemah (tidak sesuai) memengaruhi ketersediaan obat dan bahan medis habis pakai di Puskesmas "X". Tujuan penulisan ini yaitu untuk mendeskripsikan mekanisme pelaksanaan perencanaan dan pengadaan obat yang dilakukan Puskesmas. Penelitian ini merupakan penelitian deskriptif dengan pendekatan kualitatif yang bersifat observasional. Hasil penelitian ini menunjukkan bahwa pelaksanaan pengadaan obat di Puskesmas "X", terdapat dua macam sumber pembiayaan obat dan bahan medis habis pakai, yaitu melalui APBD dan JKN. Perencanaan Obat yang bersumber dari dana APBD dilakukan melalui penyusunan Laporan Kebutuhan Obat (LKO) yang dibuat setiap tahun. Perencanaan dilakukan pada akhir tahun untuk memenuhi kebutuhan obat Puskesmas selama satu tahun ke depan. Sementara itu, Proses pengadaan Obat dilakukan dengan menyusun Laporan Pemakaian dan Lembar Permintaan Obat (LPLPO) yang diajukan kepada Gudang Farmasi. Perencanaan obat yang berasal dari pembiayaan JKN dilakukan menggunakan dokumen RKA yang dibuat pada awal tahun berdasarkan jumlah kebutuhan. Mekanisme pengadaan obat dilakukan melalui pemesanan dalam e-catalogue sesuai dengan kebutuhan. Penelitian ini menyimpulkan bahwa pelaksanaan perencanaan dan pengadaan obat di Puskesmas "X" sudah sesuai dengan Permenkes Nomor 74 Tahun 2016.

Kata Kunci: perencanaan obat, pengadaan obat, peraturan, puskesmas

\section{PENDAHULUAN}

Puskesmas merupakan salah satu Fasilitas Pelayanan Kesehatan yang bertanggungjawab menyelenggarakan upaya kesehatan, baik promotif, preventif, kuratif, maupun rehabilitatif di suatu wilayah kerja. Puskesmas sebagai penyelenggara pembangunan kesehatan merupakan bagian integral dari pembangunan nasional. Tujuan diselenggarakannya pembangunan kesehatan adalah meningkatkan kesadaran, kemauan dan kemampuan hidup sehat bagi setiap orang agar terwujud derajat kesehatan masyarakat yang optimal, baik secara sosial maupun ekonomi (Kementerian Kesehatan, 2014).

Perlu berbagai penyelenggaraan upaya kesehatan yang komprehensif, terpadu dan berkesinambungan untuk mencapai tujuan. Puskesmas adalah penanggungjawab penyelenggaraan upaya kesehatan untuk jenjang tingkat pertama (Primary Healthcare) yaitu upaya kesehatan masyarakat dan upaya kesehatan perorangan, dengan mengutamakan upaya promotif 
dan preventif tanpa mengesampingkan upaya kesehatan kuratif dan rehabilitatif.

Puskesmas sebagai suatu unit fungsional berperan penting dalam mengembangkan dan membina partisipasi masyarakat dalam meningkatkan derajat kesehatannya, dengan menyelenggarakan pelayanan kesehatan secara menyeluruh dan terpadu. Oleh karena itu, dalam penyelenggaraannya dibutuhkan skill tenaga kesehatan dan pegawai puskesmas lainnya yang profesional, terdidik dan terlatih. Tentunya dalam aplikasinya sangat dibutuhkan proses belajar dan pengalaman

Ketersediaan alat, obat, bahan habis pakai, dan fasilitas kesehatan lainnya di Puskesmas, menjadi salah satu faktor yang menentukan pemenuhan aspek sarana dan prasarana yang memadai. Dalam hal ini, seluruh sumber daya yang tersedia akan dimanfaatkan secara optimal untuk mendukung pelayanan dan program kerja Puskesmas. Oleh karena itu, diperlukan kegiatan pengelolaan obat dan bahan medis habis pakai yang dilakukan secara terstruktur dan terus menerus.

Pengelolaan obat dan bahan medis habis pakai merupakan suatu kegiatan dalam pelayanan kefarmasian yang meliputi perencanaan kebutuhan, permintaan, penerimaan, penyimpanan, hingga pemantauan dan evaluasi (Rosmania \& Supriyanto, 2015). Hal ini dilakukan untuk menjamin ketersediaan obat dan bahan medis habis pakai dalam memenuhi kebutuhan pemberian pelayanan kesehatan di Puskesmas. Oleh karena itu, setiap kegiatan pengelolaan harus dilakukan sesuai dengan ketentuan dan aturan yang berlaku. Salah satu kegiatan pengelolaan obat dan bahan medis habis pakai yang sangat penting yaitu perencanaan kebutuhan obat dan bahan medis habis pakai. Hal ini penting karena merupakan titik awal dimulainya kegiatan pengelolaan obat di puskesmas.

Perencanaan kebutuhan obat dan bahan medis habis pakai yang tidak tepat dapat memengaruhi ketersediaan obat dan bahan medis habis pakai. Dampak yang mungkin terjadi adalah timbulnya kejadian stagnant dan stockout obat di Puskesmas. Kejadian stagnant dan stockout obat tentu akan memberikan dampak yang merugikan bagi Puskesmas, diantaranya yaitu peningkatan biaya akibat pemakaian obat yang tidak rasional. Hal ini tentu akan merugikan Puskesmas.

Mengingat pentingnya kegiatan pengelolaan obat dan bahan medis habis dalam kegiatan pelayanan kefarmasian di Puskesmas, maka pelaksanaan pengelolaan obat diatur dalam Permenkes Nomor 74 Tahun 2016 tentang standar pelayanan kefarmasian di Puskesmas. Tujuan penelitian ini untuk mendeskripsikan mekanisme pelaksanaan perencanaan dan pengadaan obat yang dilakukan Puskesmas.

\section{METODE}

Penelitian ini merupakan penelitian deskriptif dengan pendekatan kualitatif yang bersifat observasional. Teknik pengumpulan data primer dilakukan dengan melakukan wawancara kepada apoteker dan asisten apoteker Puskesmas "X" dengan menggunakan pedoman wawancara, dan observasi dengan menggunakan lembar Self Assessment pelaksanaan pengelolaan obat berdasarkan Permenkes Nomor 74 Tahun 2016. Pengambilan data dilakukan kurang lebih selama satu bulan, di Puskesmas " $X$ ". Data sekunder yang digunakan yaitu dokumen Standar Operasional Prosedur tentang pengelolaan Obat dan Bahan Medis Habis Pakai. Variabel dalam penelitian ini yaitu perencanaan dan pengadaan obat, yang diukur berdasarkan elemen persyaratan di dalam Permenkes Nomor 74 Tahun 2016. Elemen persyaratan perencanaan meliputi pembuatan Laporan Keadaan Obat (LKO), dan proses seleksi atau pemilihan jenis obat. Sedangkan, elemen persyaratan pengadaan obat meliputi penyusunan Laporan Pemakaian dan Lembar Permintaan Obat (LPLPO) secara rutin. Data dianalisis secara deskriptif yaitu penelitian yang menggambarkan suatu fenomena secara cermat berdasarkan permasalahan dalam penelitian. Penelitian ini menggambarkan mekanisme perencanaan dan pengadaan obat yang dilakukan oleh Puskesmas "X". Hasil penelitian akan digambarkan dengan menggunakan tabel yang meliputi variabel observasi dan pelaksanaan elemen yang dipersyaratkan di Puskesmas " $X$ ". Hasil penelitian ini akan menggambarkan kesesuaian antara pelaksanaan perencanaan dan pengadaan obat di Puskesmas dengan Permenkes Nomor 74 Tahun 2016.

\section{HASIL DAN PEMBAHASAN}

Peraturan Menteri Kesehatan Nomor 74 Tahun 2016 tentang standar pelayanan kefarmasian di Puskesmas menyebutkan bahwa pelayanan kefarmasian di Puskesmas merupakan bagian dari penyelenggaraan pelayanan kesehatan yang berperan dalam peningkatan mutu pelayanan kesehatan. Pelayanan kefarmasian dilakukan secara terpadu yang meliputi kegiatan pengelolaan sediaan farmasi dan kegiatan pelayanan farmasi klinik. Dukungan sarana dan prasarana yang memada sangat diperlukan dalam meningkatkan efektivitas pelayanan.

Pengelolaan sediaan farmasi salah satu bagian dari penyelenggaraan kegiatan pelayanan kefarmasian di Puskesmas. Pengelolaan obat dan bahan medis habis pakai di Puskesmas meliputi perencanaan kebutuhan, permintaan, penerimaan, penyimpanan, pendistribusian, pengendalian, Administrasi (pencatatan, pelaporan, dan pengarsipan), serta pemantauan dan evaluasi pengelolaan. Kegiatan pengelolaan ini bertujuan untuk menjamin ketersediaan dan keterjangkauan sediaan farmasi dan bahan habis pakai yang efektif efisien, dan rasional. Selain itu, juga meningkatkan kompetensi dan kemampuan tenaga kefarmasian, mewujudkan sistem informasi manajemen, dan melaksanakan pengendalian mutu pelayanan (Kemenkes RI, 2016). Selain itu, penyelenggaraan pengelolaan obat ini juga merupakan bagian dari proses manajemen logistik yang dilakukan oleh Puskesmas. 
Manajemen logistik merupakan suatu proses pengelolaan yang strategis terhadap pemindahan dan penyimpanan barang, suku cadang dan barang jadi dari para supplier, di antara fasilitas perusahaan dan kepada para pelanggan (Bowersox, 2006). Selain itu, manajemen logistik juga merupakan sekumpulan fungsi yang dinamis, dan fleksibel sesuai dengan kondisi lingkungan serta kendala yang dihadapi (Rushton, et al., 2010). Tujuan manajemen logistik adalah untuk menjamin ketersediaan barang atau bahan dalam jumlah yang tepat dengan kualitas dan mutu yang terjamin, mengoptimalkan penggunaan sumber daya dan biaya dalam rangka menjamin pelaksanaan seluruh kegiatan manajemen logistik (Subagya, 1994).

Ketersediaan obat di Puskesmas menjadi salah satu hal yang paling penting dalam kualitas pelayanan kesehatan Puskesmas. Perencanaan kebutuhan dan pengadaan obat berperan penting dalam menjamin ketersediaan obat di Puskesmas. Perencanaan kebutuhan merupakan suatu kegiatan pemilihan dan penetapan jumlah obat yang dibutuhkan untuk memenuhi pelayanan kesehatan. Sedangkan, pengadaan merupakan suatu proses pemenuhan kebutuhan operasional sediaan farmasi yang telah ditetapkan dalam perencanaan obat (Rosmania \& Supriyanto, 2015). Kegiatan pengelolaan ini, dilaksanakan oleh Unit Obat Puskesmas "X" Surabaya berdasarkan Standar Prosedur Operasional (SPO) yang telah disusun dengan mengacu pada peraturan perundang-undangan yang berlaku, sebagai acuan dalam implementasi.

Implementasi kegiatan pengadaan obat dan bahan medis habis pakai di Puskesmas, terdiri dari dua sumber pembiayaan obat dan bahan medis habis pakai, diantaranya yaitu melalui dana APBD dan dana Kapitasi Puskesmas atau JKN. Kedua pembiayaan ini dalam implementasinya tentu memiliki perbedaan, terutama berkaitan dengan pengadaan obat. Hasil observasi pengadaan obat akan disajikan dalam tabel 1.

\section{Perencanaan dan Pengadaan Obat Pembiayaan APBD}

Perencanaan dan kebutuhan obat yaitu proses kegiatan seleksi sediaan farmasi dan bahan medis habis pakai untuk menentukan jenis dan jumlah sediaan farmasi dalam rangka pemenuhan kebutuhan puskesmas (Kemenkes RI, 2016). Perencanaan bertujuan untuk memperkirakan jenis dan jumlah sediaan farmasi yang dibutuhkan, dan meningkatkan efisiensi penggunaan obat. Dalam proses ini juga mencakup penentuan kebutuhan secara rinci (detailering) dengan memperhitungkan semua faktor yang memengaruhi penentuan kebutuhan (Aditama, 2003).

Pelaksanaan pengelolaan obat di Puskesmas mencakup 4 fungsi dasar yaitu perumusan kebutuhan, pengadaan, distribusi, dan penggunaan obat. Selain itu, untuk bisa berjalan dengan maksimal, maka harus didukung oleh pembiayaan yang berkesinambungan, pengelolaan sistem informasi yang memadai, serta manajemen dan pengembangan sumber daya manusia (Hartono, 2007). Implementasi tersebut dilakukan sesuai dengan peraturan dan ketentuan yang berlaku.

Berdasarkan tabel 1 pengelolaan obat di Puskesmas " $X$ " diawali dengan kegiatan pengadaan obat yang didalamnya mencakup perencanaan kebutuhan obat untuk memenuhi kebutuhan dalam pelayanan kesehatan di Puskesmas "X". Perencanaan kebutuhan ini dilakukan dengan membuat Laporan Kebutuhan Obat (LKO) yang dibuat setiap tahun, dilakukan pada akhir tahun untuk perencanaan kebutuhan obat Puskesmas selama satu tahun ke depan. Metode yang digunakan dalam kegiatan perencanaan kebutuhan obat adalah dengan mempertimbangkan pola konsumsi atau pemakaian obat tahun sebelumnya. Perhitungan pola konsumsi perlu memperhatikan: 1) Pengumpulan dan pengolahan data, 2) Proses analisis data, 3) Perhitungan kebutuhan obat, 4) Penyesuaian jumlah kebutuhan dengan alokasi dana (Hartono, 2007).

Tabel 1. Perencanaan Obat Berdasarkan Permenkes 74 Tahun 2016 di Puskesmas "X" Surabaya Tahun 2017

\begin{tabular}{|c|c|c|c|c|}
\hline \multirow[b]{2}{*}{ No. } & \multirow[b]{2}{*}{ Elemen Persyaratan } & \multicolumn{2}{|c|}{ Pelaksanaan di Lapangan } & \multirow[b]{2}{*}{ Hasil Observasi } \\
\hline & & Dilakukan & $\begin{array}{c}\text { Tidak } \\
\text { Dilakukan }\end{array}$ & \\
\hline \multicolumn{5}{|c|}{ Perencanaan Kebutuhan } \\
\hline 1. & $\begin{array}{l}\text { Perencanaan Kebutuhan obat } \\
\text { dilaksanakan oleh Ruang Farmasi } \\
\text { Puskesmas secara rutin. }\end{array}$ & $\sqrt{ }$ & & $\begin{array}{l}\text { Perencanaan kebutuhan dilakukan dengan } \\
\text { membuat Laporan Kebutuhan Obat (LKO), } \\
\text { yang dibuat setiap tahun. }\end{array}$ \\
\hline 2. & $\begin{array}{l}\text { Proses Seleksi dilakukan dengan } \\
\text { mempertimbangkan diantaranya yaitu } \\
\text { Pola Konsumsi periode sebelumnya, } \\
\text { Pola Penyakit, data mutasi sediaan } \\
\text { farmasi, dan rencana pengembangan. }\end{array}$ & $\sqrt{ }$ & & $\begin{array}{l}\text { Dalam kegiatan perencanaan kebutuhan } \\
\text { dilakukan secara periodik berdasarkan } \\
\text { pemakaian obat periode sebelumnya yang } \\
\text { telah direkap dan dihitung. }\end{array}$ \\
\hline 3. & $\begin{array}{l}\text { Proses seleksi sediaan farmasi dan } \\
\text { bahan medis habis pakai mengacu } \\
\text { pada Daftar Obat Esensial Nasional } \\
\text { (DOEN), dan Formularium Nasional. }\end{array}$ & $\sqrt{ }$ & & $\begin{array}{l}\text { Perencanaan kebutuhan sediaan farmasi } \\
\text { dan bahan medis habis pakai, mengacu } \\
\text { pada Daftar Obat Esensial Nasional } \\
\text { (DOEN), dan Formularium Nasional. Oleh } \\
\text { karena itu, dapat dikatakan sudah sesuai } \\
\text { dengan Permenkes No. } 74 \text { Tahun } 2016 \text {. }\end{array}$ \\
\hline
\end{tabular}


Pola yang seharusnya digunakan yaitu melalui pendekatan epidemiologis berdasarkan pola penyakit, akan tetapi masih belum bisa dilakukan. Selain itu, petugas unit obat juga membagikan lembar permintaan obat yang dibutuhkan untuk satu tahun ke depan kepada setiap poli yang ada di Puskesmas (Kemenkes RI, 2016).

Petugas unit obat juga membagikan lembar permintaan obat yang dibutuhkan untuk satu tahun ke depan kepada setiap poli yang ada di Puskesmas " $X$ ". Selanjutnya, dokter atau tenaga medis dari setiap poli akan mengisi jenis obat yang dibutuhkan selama satu tahun ke depan. Permintaan dari setiap poli tersebut, selanjutnya oleh penanggung jawab unit obat akan dianalisis dan dimasukkan ke dalam Rencana Kerja Anggaran (RKA) untuk diusulkan kepada Dinas Kesehatan Kota Surabaya.

Hasil wawancara didapatkan bahwa perencanaan kebutuhan, juga dilakukan proses seleksi sediaan farmasi dan bahan medis habis pakai yang dibutuhkan oleh puskesmas. Proses seleksi tersebut dilakukan dengan mengacu pada Daftar Obat Esensial Nasional (DOEN) dan formularium nasional, sebagaimana ketentuan dalam peraturan perundangundangan yang berlaku. Selain itu, untuk mengetahui jumlah obat yang dibutuhkan untuk satu tahun, maka dilakukan perhitungan kebutuhan berdasarkan jumlah pemakaian obat pada tahun sebelumnya di Puskesmas (Rosmania \& Supriyanto, 2015). Perhitungan jumlah kebutuhan sebagaimana yang telah diatur dalam Standar Prosedur Operasional Pemesanan dan Pengelolaan obat Puskesmas " $X$ ", dilakukan dengan mengacu pada rumus yaitu:

\section{Kebutuhan = rekapitulasi pemakaian 1 th $\times 18$ bulan}

Keterangan : 18 bulan $=12$ bulan +6 bulan

Gambar 1. Rumus Perhitungan Perencanaan Kebutuhan Puskesmas

Pengaturan Standar Prosedur Operasional Puskesmas " $X$ " mengenai pemesanan dan pengelolaan tidak sesuai dengan ketentuan yang ada di dalam Permenkes Nomor 74 Tahun 2016. Ketidaksesuaian terletak pada penamaan dokumen Standar Prosedur Operasional yaitu Pemesanan dan Pengelolaan Obat. Secara umum, konsep perencanaan dengan pemesanan sudah jelas berbeda. Selain itu, terdapat perbedaan ketentuan tahapan pelaksanaan perencanaan dan pemesanan obat di Puskesmas.

Ketidaksesuaian penamaan dalam Standar Prosedur Operasional seharusnya diubah agar tidak menimbulkan persepsi yang salah pada petugas kefarmasian. Selain itu, ketidaksesuaian penamaan juga dapat menimbulkan adanya kesalahan dalam pelaksanaan pelayanan kefarmasian yang dilakukan Puskesmas yang dapat memengaruhi mutu pelayanan.

Perhitungan kebutuhan dilakukan untuk mengetahui jumlah obat yang dibutuhkan untuk satu periode. Hasil perhitungan yang didapatkan, dijadikan sebagai bahan analisis bersama dengan rekapitulasi permintaan dari setiap poli sehingga menghasilkan usulan jumlah kebutuhan obat. Usulan tersebut kemudian dimasukkan ke dalam Laporan Keadaan Obat dan usulan obat untuk diajukan kepada Dinas Kesehatan Kota Surabaya (Kemenkes RI, 2016).

Sementara itu, apabila terjadi suatu hal yang tidak terduga seperti Kejadian Luar Biasa, Bencana Alam, dan sebagainya Puskesmas dapat mengajukan permintaan khusus. Perencanaan kebutuhan sediaan farmasi dalam hal ini yaitu obat dilakukan untuk menentukan jumlah dan jenis obat dan bahan medis habis pakai dalam rangka pemenuhan kebutuhan puskesmas. Selain itu, hal ini juga bertujuan untuk meningkatkan penggunaan obat yang rasional dan efisiensi penggunaan obat (Subagya, 1994).

Perencanaan kebutuhan obat di puskesmas harus dilakukan secara tepat untuk menghindari terjadinya kejadian stagnant dan stockout obat di puskesmas. Ketidaktepatan perencanaan kebutuhan akan mengakibatkan adanya ketidakefisienan dalam jumlah persediaan obat yang ada di puskesmas. Selain itu, hal ini juga akan memengaruhi mutu pelayanan di puskesmas, dan bahkan dapa menimbulkan kerugian bagi puskesmas (Hadidah, 2016)

Kegiatan pengadaan obat di Puskesmas mencakup penyusunan dan pengajuan permintaan obat kepada Gudang Farmasi sesuai dengan kebutuhan. Pengadaan dilakukan sebagai bentuk realisasi dari perencanaan kebutuhan yang telah dilakukan oleh Puskesmas. Efektivitas kegiatan pengadaan ditunjukkan melalui ketersediaan obat, kesesuaian jumlah obat dengan kebutuhan, kesesuaian harga obat (Hadidah, 2016).

Tabel 2. Pelaksanaan Pengadaan Obat Berdasarkan Permenkes 74 Tahun 2016 di Puskesmas "X" Surabaya Tahun 2017

\begin{tabular}{|c|c|c|c|c|}
\hline \multirow[b]{2}{*}{ No. } & \multirow[b]{2}{*}{ Elemen Persyaratan } & \multicolumn{2}{|c|}{ Pelaksanaan di Lapangan } & \multirow[b]{2}{*}{ Hasil Observasi } \\
\hline & & Dilakukan & $\begin{array}{c}\text { Tidak } \\
\text { Dilakukan }\end{array}$ & \\
\hline
\end{tabular}

\begin{tabular}{cll}
\hline Permintaan & \\
\hline 1. & Permintaan Sediaan Farmasi & \\
dan Bahan Medis Habis & Permintaan sediaan farmasi dan bahan medis \\
Pakai diajukan kepada Dinas & habis pakai dilakukan melalui LPLPO yang telah \\
Kesehatan Kota Surabaya. & dibuat dan ditandatangani oleh Kepala Puskesmas. \\
& Pengajuan tersebut dilakukan secara rutin kepada \\
& Dinas Kesehatan Kota Surabaya, dapat dikatakan \\
& sudah sesuai dengan Permenkes 74 Tahun 2016. \\
\hline
\end{tabular}


Berdasarkan tabel 2, Puskesmas melakukan permintaan obat dan bahan medis habis pakai dengan membuat Laporan Pemakaian dan Lembar Permintaan Obat (LPLPO). Laporan ini dibuat setiap bulan oleh petugas farmasi berdasarkan pemakaian pada bulan sebelumnya yang telah disetujui oleh Kepala Puskesmas dan diajukan kepada gudang farmasi Kota Surabaya (Kemenkes RI, 2016). Tujuan permintaan yaitu untuk memenuhi kebutuhan operasional terhadap sediaan farmasi dan bahan medis habis pakai di puskesmas dalam satu periode.

Berdasarkan hasil wawancara, diketahui bahwa petugas melakukan rekapitulasi pemakaian obat selama satu bulan terakhir, baik dari poli pelayanan, Puskesmas Pembantu, dan sebagainya serta melakukan perhitungan stock opname bulan kemarin, untuk permintaan bulan berikutnya.

Gudang farmasi Kota Surabaya, selanjutnya akan memverifikasi permintaan tersebut berdasarkan stok optimum dan sisa stok yang ada. Kemudian, puskesmas akan mendapatkan pemberitahuan jadwal pengambilan obat dari Gudang Farmasi Kota Surabaya. Dalam hal ini, penambahan permintaan jumlah obat kepada gudang farmasi Kota Surabaya bisa langsung dikomunikasikan kepada gudang farmasi dengan catatan jumlah yang diminta tidak melebihi batas jumlah kebutuhan selama satu tahun yang telah disetujui oleh dinas kesehatan. Dalam hal ini, secara umum pelaksanaan pengadaan obat dan bahan medis habis pakai yang dilakukan oleh Puskesmas dapat dikatakan sesuai dengan Permenkes Nomor 74 Tahun 2016.

\section{Perencanaan dan Pengadaan Obat Pembiayaan JKN}

Selain perencanaan kebutuhan obat yang bersumber dari APBD, terdapat perencanaan kebutuhan obat yang sumber pembiayaan berasal dari dana kapitasi puskesmas atau JKN Perencanaan kebutuhan obat JKN, dilakukan dengan menggunakan dokumen RKA yang dibuat pada awa tahun berdasarkan jumlah kebutuhan (Kemenkes RI, 2016). Hasil wawancara menunjukkan bahwa petugas farmasi melakukan rekapitulasi permintaan obat dari setiap poli pelayanan yang ada di Puskesmas. Permintaan dari setiap poli tersebut, selanjutnya oleh penanggung jawab unit obat akan dianalisis dan disesuaikan dengan anggaran yang dimiliki. Selanjutnya, jumlah obat yang sudah sesuai dengan anggaran tersebut dimasukkan ke dalam Rencana Kerja Anggaran (RKA).

Kegiatan perencanaan kebutuhan obat ini menjadi dasar dari implementasi pengelolaan obat di puskesmas. Perencanaan kebutuhan obat yang tepat akan menghasilkan jumlah dan jenis obat yang tepat sesuai dengan kebutuhan, mencegah terjadinya kekosongan stok obat, meningkatkan penggunaan obat secara rasional, dan meningkatkan efisiensi penggunaan obat (Aditama, 2003).

Data obat yang akan dipesan, kemudian di breakdown satu per satu, untuk mengidentifikasi waktu pemesanan dan juga rencana kedatangan serta penerimaan dari obat yang dipesan. Selanjutnya, dokumen RKA diajukan kepada Dinas Kesehatan
Surabaya melalui website, oleh Dinas Kesehatan akan ditarik data dan di breakdown. Kemudian, data tersebut dimasukkan ke dalam AKP dari setiap bulan, berdasarkan koordinasi dengan dinas kesehatan. Selanjutnya, pemesanan obat dilakukan melalui e-catalogue sesuai dengan kebutuhan dan alokasi anggaran. Selanjutnya, distributor akan menyetujui pemesanan, dan barang akan dikirim ke Gudang Farmasi Kota Surabaya.

Pengadaan obat merupakan suatu proses pemenuhan kebutuhan operasional obat dan bahan medis habis pakai yang dibutuhkan oleh puskesmas, sebagai bentuk realisasi dari perencanaan kebutuhan obat yang telah dilakukan sebelumnya. Hal ini dilakukan untuk menjamin ketersediaan obat dengan jumlah yang tepat di waktu yang tepat pula (Hadidah, 2016). Dalam hal ini, ketidaktepatan perencanaan obat yang dilakukan sebelumnya akan memengaruhi proses pengadaan obat yang dilakukan puskesmas. Kedua proses tersebut saling berhubungan dan menentukan ketersediaan obat dan bahan medis habis pakai di puskesmas dalam pemberian pelayanan kesehatan kepada pasien.

\section{Permasalahan dalam Pengadaan}

Hasil wawancara dan observasi menunjukkan bahwa secara umum, pelaksanaan pengadaan obat di Puskesmas telah sesuai dengan Permenkes Nomor 74 Tahun 2016. Akan tetapi, masih terdapat beberapa kendala yang ditemukan dalam pelaksanaan pengadaan obat. Beberapa kendala yang ditemui diantaranya yaitu: Pertama, Kegiatan Pengadaan membutuhkan waktu yang cukup lama. Proses pengadaan obat dan bahan medis habis pakai yang dilakukan oleh Puskesmas membutuhkan waktu yang relatif lama. Hal ini disebabkan karena adanya prosedur administratif yang harus dipersiapkan dalam melakukan pengadaan obat dan bahan medis habis pakai. Sementara, kebutuhan puskesmas terhadap obat dan bahan medis habis pakai sangat dibutuhkan untuk mendukung pemberian pelayanan kesehatan. Selain itu, kurangnya komitmen distributor dalam melakukan pengiriman barang, sehingga fraktur sudah ada tetapi, barang belum datang. Kedua, Puskesmas tidak bisa melakukan pengadaan di luar periode pengadaan obat dan bahan medis habis pakai. Kegiatan pengadaan obat dan bahan medis habis pakai di Puskesmas dilakukan dalam satu periode waktu, dan Puskesmas tidak boleh melakukan pengadaan obat dan bahan medis habis pakai di luar periode waktu pengadaan kecuali dalam keadaan yang darurat seperti KLB, Bencana Alam, dan sebagainya.

Kebutuhan obat untuk mendukung pelayanan kesehatan dapat dikatakan sangat tinggi. Oleh karena itu, pengadaan obat dan bahan medis habis pakai harus dilakukan secara cermat dan rasional sehingga mampu memenuhi kebutuhan puskesmas. Ketiga, kurangnya pemantauan oleh Dinas Kesehatan terhadap Distributor Obat. Disamping, kurangnya komitmen dari pihak distributor obat dan bahan medis habis pakai, pengawasan yang dilakukan oleh Dinas Kesehatan Kota juga masih kurang, terhadap distributor yang menyuplai obat dan bahan medis habis pakai kepada Puskesmas. Hal ini ditunjukkan 
oleh kurangnya ketegasan Dinas Kesehatan Kota kepada distributor yang tidak mengirimkan barang tepat waktu. Sementara, petugas puskesmas tidak bisa memberikan tindak lanjut secara langsung karena yang melakukan kerja sama dengan distributor adalah Dinas Kesehatan Kota.

Perlu adanya regulasi yang secara jelas dapat menjembatani pengadaan obat di Puskesmas, mengingat terdapat dua sumber pembiayaan obat yang memerlukan administrasi dan dokumen pengadaan yang berbeda. Kedua sumber pembiayaan tersebut, yaitu APBD dan JKN yang menciptakan dua sistem pengadaan obat dan bahan medis habis pakai di Puskesmas. Peraturan yang berlaku, sebaiknya harus bisa mengakomodasi pelaksanaan dua sistem tersebut agar tidak saling tumpang tindih dan menghambat pelaksanaan kegiatan pengelolaan obat dan bahan medis habis pakai. Dalam hal ini, Kementerian Kesehatan harus bisa mengatur pelaksanaan pengadaan obat dan bahan medis habis pakai agar bisa berjalan sesuai dengan ketentuan dalam rangka memenuhi kebutuhan obat dan bahan medis habis pakai di Puskesmas.

\section{SIMPULAN}

Kegiatan pengelolaan obat dan bahan medis habis pakai di Puskesmas, terdiri dari dua sumber pembiayaan, diantaranya yaitu APBD dan JKN. Secara umum, pelaksanaan pengadaan obat sesuai dengan Permenkes Nomor 74 Tahun 2016. Implementasi pengadaan obat dan bahan medis habis pakai di puskesmas masih terdapat beberapa kendala diantaranya yaitu kegiatan pengadaan yang membutuhkan waktu yang lama, Puskesmas tidak bisa melakukan pengadaan di luar periode pengadaan obat dan bahan medis habis pakai, dan kurangnya pemantauan Dinas Kesehatan Kota terhadap distributor obat. Perlu adanya pengembangan suatu regulasi yang secara jelas mengatur dan menjembatani pelaksanaan pengadaan obat yang berasal dari kedua sumber pembiayaan baik APBD maupun JKN.

\section{DAFTAR PUSTAKA}

Aditama, T. 2003. Manajemen Administrasi Rumah Sakit. Jakarta: Universitas Indonesia Press.

Bowersox, D. 2006. Manajemen Logistik. I ed. Jakarta: Bumi Aksara.

Hadidah, I.S. 2016. Analisis Kerugian Akibat Kejadian Obat Stagnant dan Stockout di Instalasi Farmasi: Studi di UPT Rumah Sakit Mata Masyarakat Jawa Timur. in: Skripsi. Surabaya: Universitas Airlangga.

Hartono, J.P. 2007. Analisis Proses Perencanaan Kebutuhan Obat Publik untuk Pelayanan Kesehatan Dasar (PKD) di Puskesmas se Wilayah Kerja Dinas Kesehatan Kota Tasikmalaya. In Tesis. Semarang: Universitas Diponegoro.

Kemenkes RI. 2016. Permenkes Nomor 74 Tahun 2016. Jakarta: Kementerian Kesehatan Republik Indonesia.

Kementerian Kesehatan. 2014. Peraturan Menteri Kesehatan Nomor 75 Tahun 2014 Tentang Puskesmas. Jakarta: Kementerian Kesehatan.

Kementerian Kesehatan. 2016. Permenkes 74 Tahun 2016 Tenteng Sandar Pelayanan Kefarmasian di Puskesmas. Jakarta: Kementerian Kesehatan.

Menteri Kesehatan Nasional. 2004. Sistem Kesehatan Nasional, Jakarta: s.n.

Rosmania, F.A. \& Supriyanto, S. 2015. Analisis Pengelolaan Obat Sebagai Dasar Pengendalian Safety Stock pada Stagnant dan Stockout Obat. Jurnal Administrasi Kesehatan Indonesia, 3 (1), pp. 1-10.[Online]. Tersedia di <www.ejournal.unair.ac.id/index.php/JAKI/article/ download/1483/1144>

Rushton, A., Croucher, P. \& Baker, P. 2010. The Handbook of Logistics \& Distribution Management. 4th Edition ed. London: Kokan Page.

Subagya. 1994. Manajemen Logistik. Jakarta: CV. Hanmas. 